\title{
The Process of Electoral Reform in Canada: Democratic and Constitutional Constraints
}

Yasmin Dawood

University of Toronto

Follow this and additional works at: https://digitalcommons.osgoode.yorku.ca/sclr

Part of the Law Commons

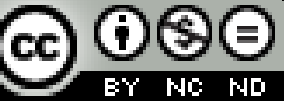

This work is licensed under a Creative Commons Attribution-Noncommercial-No Derivative Works 4.0 License.

\section{Citation Information}

Dawood, Yasmin. "The Process of Electoral Reform in Canada: Democratic and Constitutional Constraints." The Supreme Court Law Review: Osgoode's Annual Constitutional Cases Conference 76. (2016).

https://digitalcommons.osgoode.yorku.ca/sclr/vol76/iss1/16 


\title{
The Process of Electoral Reform in Canada: Democratic and Constitutional Constraints
}

\author{
Yasmin Dawood*
}

\section{INTRODUCTION}

This article considers the process by which electoral reform ought to take place, focusing in particular on the democratic and constitutional constraints that bear on electoral reform. It addresses two inter-related issues: first, whether any particular process, such as a referendum, is required as a normative matter to establish the democratic legitimacy of a given reform; and second, whether a constitutional amendment involving provincial consent is required to implement electoral reform.

This article argues, with respect to the first issue, that while no one process is mandated for electoral reform, it is nevertheless important for the process to be and appear to be democratically legitimate. Part I considers a number of possible mechanisms, including a citizens' assembly, a commission, a referendum and an all-party parliamentary committee, and it does so by drawing on provincial and comparative international experience with electoral reform. Part II argues that although no single process is required, the process must be and appear to be democratically legitimate. In order for the process of electoral reform to be democratically legitimate, it must visibly follow the norms of political neutrality, consultation, and deliberation.

\footnotetext{
* Canada Research Chair in Democracy, Constitutionalism, and Electoral Law and Associate Professor of Law and Political Science, University of Toronto. I am grateful to Benjamin Berger, Adam Dodek, Peter Hogg, Sonia Lawrence, Emmett Macfarlane, Carissima Mathen, Pippa Norris, Michael Pal, Peter Russell, Lorne Sossin, Carolyn Tuohy, an anonymous reviewer, and participants at the Osgoode Constitutional Cases Conference, the Asper Centre Conference on the State of Canada's Constitutional Democracy, and the University of Toronto School of Public Policy and Governance Roundtable on Electoral Reform for helpful comments and discussions. Special thanks to Jennifer Che, Maryam Shahid and Logan St. John-Smith for superb research assistance. The research for this article was supported by the Social Sciences and Humanities Research Council of Canada.
} 
Part III turns to the question of whether a constitutional amendment involving provincial consent is required for electoral reform. It argues that prior to the Senate Reference ${ }^{1}$ the Supreme Court had recognized in many of its cases that the electoral system is political in nature but nonetheless subject to certain constitutional limits. Part III sets out these constitutional limits (which include voter rights and the principle of provincial representation) and argues that the majority of the current electoral reform proposals would not violate these limits. Given the Court's statements that the choice of electoral model falls within the domain of Parliament, Part III claims that Parliament would be able to change the electoral system without provincial consent under the Court's prior precedents.

Part III then addresses the Senate Reference to determine whether the Court's decision and, in particular, its expansive use of the concept of "constitutional architecture" has changed the legal landscape such that Parliament would now be required to secure provincial consent under the general amending formula in order to usher in electoral change. This article argues that given the salient differences between Senate reform and electoral reform, it would be possible for the Supreme Court to distinguish the Senate Reference and find that its earlier precedents on the electoral system remain valid. The article concludes that electoral reform can likely proceed without a constitutional amendment involving provincial consent, provided that the reform is consistent with certain constitutional requirements.

\section{PROCESS OPTIONS FOR ELECTORAL REFORM}

Prior to the federal election, the Liberal Party pledged "that 2015 will be the last federal election conducted under the first-past-the-post voting system". ${ }^{2}$ There are many alternatives to the current first-past-the-post ("FPTP") electoral system, including, for instance, various kinds of proportional representation ("PR"), mixed voting schemes such as the mixed member proportional ("MMP") system, and preferential ballots. ${ }^{3}$

\footnotetext{
1 Reference re Senate Reform, [2014] S.C.J. No. 32, 2014 SCC 32, [2014] 1 S.C.R. 704 (S.C.C.) [hereinafter "Senate Reference"].

See Liberal Party of Canada, "A New Plan for a Strong Middle Class" (2015) at 27, online: Liberal Party of Canada <https://www.liberal.ca/files/2015/10/New-plan-for-a-strong-middleclass.pdf>.

3 For a discussion of the most common options suggested in Canada, see Harold J. Jansen \& Alan Siaroff, "Regionalism and Party Systems: Evaluating Proposals to Reform Canada's Electoral System" in Henry Milner, ed., Steps Toward Making Every Vote Count: Electoral System Reform in Canada and Its Provinces (Peterborough, ON: Broadview Press, 2004), at 43-63; Louis Massicotte,
} 
These systems all have advantages and disadvantages, and any choice among them involves a consideration of various trade-offs. In addition, electoral reform has partisan implications in the sense that different systems can augment or depress a party's chances of electoral success.

Not only are there many kinds of electoral systems, there are also many possible processes of electoral reform. This section examines a number of process options for electoral reform, drawing on provincial, federal, and international experience.

\section{Citizens' Assembly}

One process option is the citizens' assembly, previously used in both British Columbia and Ontario. ${ }^{4}$ In British Columbia, a citizens' assembly selected the single transferable vote ("STV") system for the province in $2004 .^{5}$ The Assembly was composed of 160 randomly selected members, and during its year-long deliberation it held 50 public hearings. ${ }^{6}$ In Ontario, an all-party committee studying the electoral system recommended the establishment of a Citizens' Assembly on Electoral Reform. This assembly recommended in 2007 that the province adopt an MMP system. ${ }^{7}$

\section{Electoral Reform Commission}

Another possible mechanism for electoral reform is to establish a commission. In 2004, for instance, the New Brunswick Commission on Legislative Democracy recommended that the province adopt a regional MMP system. ${ }^{8}$ In 2004, Prince Edward Island established an eight-person

"Electoral Reform in Canada" in André Blais, ed., To Keep or Change First Past the Post (New York: Oxford University Press, 2008), at 112-39.

$4 \quad$ Mark E. Warren \& Hilary Pearse, eds., Designing Deliberative Democracy: British Columbia Citizens' Assembly (New York: Cambridge University Press, 2008).

5 Canada, Library of Parliament, Electoral Reform Initiatives in Canadian Provinces (Ottawa: Library of Parliament, August 2009), at 2, online: Parliament of Canada <http://www.parl.gc.ca/ content/lop/researchpublications/prb0417-e.htm>.

$6 \quad$ British Columbia Citizen's Assembly on Electoral Reform, Making Every Vote Count: The Case of Electoral Reform in British Columbia, Final Report (Victoria: British Columbia Citizen's Assembly on Electoral Reform, December 2004), at 1, 10, online: 〈http://citizensassembly.arts.ubc.ca〉. Citizens' Assembly on Electoral Reform, One Ballot, Two Votes: A New Way to Vote in Ontario (Toronto: Citizens' Assembly on Electoral Reform, 2007), at 1, online: Ontario Citizens' Assembly on Electoral Reform <http://www.citizensassembly.gov.on.ca〉.

8 New Brunswick, Commission on Legislative Democracy, Final Report and Recommendations (Fredericton: Commission on Legislative Democracy, December 2014), at 17, online: Elections New Brunswick <http://www.electionsnb.ca/content/dam/enb/pdf/cld/CLDFinalReport-e.pdf>. 
commission, which was charged with refining an MMP system for the province. ${ }^{9}$ Earlier, in 2003, a one-person commission headed up by former provincial Chief Justice Carruthers recommended that Prince Edward Island should adopt either an MMP or STV system. ${ }^{10}$

A number of independent organizations and bodies have also developed policy proposals for electoral reform. For example, the Law Commission of Canada recommended the adoption of an MMP system at the federal level. ${ }^{11}$ The Broadbent Institute recently issued a report recommending proportional representation. ${ }^{12}$ Fair Vote Canada promotes the introduction of an element of proportional representation into elections for all levels of government in Canada. ${ }^{13}$

\section{Referendum}

Canada can also usher in electoral reform by holding a referendum. There have been four provincial referendums on electoral reform to date, though none of them have been successful. In British Columbia, a referendum on the proposed STV system was held in 2005. The proposal received 57 per cent support across the province, which fell short of the 60 per cent threshold that was required. ${ }^{14}$ A second referendum on the STV system, which was held in 2009 , only garnered 39 per cent support among the ballots cast. ${ }^{15}$ In Ontario, the proposed MMP system was subject to a referendum held during the 2007 provincial election. The referendum failed with support from only 36.9 per cent of voters. ${ }^{16}$ In November 2005, Prince Edward Island held a plebiscite on a proposed

\footnotetext{
9 Commission on Prince Edward Island's Electoral Future, 2005 Commission on Prince Edward Island's Electoral Future Final Report (Charlottetown: Commission on Prince Edward Island's Electoral Future, 2005), at 5, online: Government of PEI <http://www.gov.pe.ca/photos/ original/elec_elecrfrm05.pdf>.

10 Commission on Electoral Reform in Prince Edward Island, 2003 Prince Edward Island Electoral Reform Commission Report (Charlottetown: Commission on Electoral Reform in Prince Edward Island, 2003), at 98, online: Government of PEI <http://www.gov.pe.ca/photos/ original/er_premier2003.pdf>.

11 Law Commission of Canada, Voting Counts: Electoral Reform for Canada (2004), online: Law Commission of Canada, <http://publications.gc.ca〉.

12 David Moscrop, An Electoral System for All: Why Canada Should Adopt Proportional Representation (2016), online: Broadbent Institute <http://www.broadbentinstitute.ca/democratic

13 Fair Vote Canada, About (FAQ) (2015) online: Fair Vote Canada <http://campaign2015. fairvote.ca>.

14 Electoral Reform Initiatives, supra, note 5, at 2

$15 \quad I d$., at 3.

16 Ontario Citizens' Assembly on Electoral reform, supra, note 7, at 15.
} renewal>. 
MMP system. ${ }^{17}$ Only a third of the electorate voted, and of those who voted, only 36 per cent endorsed electoral reform, which was far short of the required threshold of 60 per cent of the vote provincially. ${ }^{18}$

At the national level, there have only been three referendums. ${ }^{19}$ The first one considered the issue of prohibition; ${ }^{20}$ the second considered the issue of conscription during World War II; and the third considered the proposed constitutional changes in the Charlottetown Accord. A majority of voters opposed the Accord nationally, and the referendum was defeated in six provinces. ${ }^{21}$ There have also been a number of referendums at the provincial level on other topics, including the creation of Nunavut in 1982 and 1992,22 and Quebec's two secessionist referendums in 1980 and $1995 .^{23}$

\section{All-Party Parliamentary Committee}

The Liberal government has established an all-party parliamentary committee to propose a new electoral system. While parliamentary committees have been used in the provinces as part of the process of proposed electoral reform, these committees are usually paired with at least one other mechanism, such as a referendum, a citizens' assembly, or a commission. For example, in Ontario, an all-party parliamentary committee recommended that the details of electoral reform be determined by a citizens' assembly, the results of which were put to a referendum. Likewise, in Quebec, a parliamentary committee worked in conjunction with an eight-member citizens' committee. ${ }^{24}$

\footnotetext{
17 Legislative Assembly of Prince Edward Island, White Paper on Democratic Renewal (Charlottetown: Legislative Assembly of Prince Edward Island, July 2015), at 9, online: Legislative Assembly of Prince Edward Island <http://www.assembly.pe.ca/democraticrenewal/>.

19 Vincent Lemieux \& S.J.R. Noël, "Referendum” The Canadian Encyclopedia (June 6, 2015) online: The Canadian Encyclopedia <http://www.thecanadianencyclopedia.ca/en/article/referendum/>.

20 Benoit Dostie \& Ruth Dupré, “'The People's Will': Canadians and the 1898 referendum on alcohol prohibition" (2012) 49 Explorations in Economic History 498, at 503.

21 Lawrence Leduc, "Canada's Constitutional Referendum of 1992: A 'Great Big No"" (1993) 12:3 Electoral Studies 257, at 263.

22 Patrick Boyer, Direct Democracy in Canada: The History and Future of Referendums (Toronto: Dundurn Press, 1992), at 180.

23 Lemieux \& Noël, "Referendum," supra, note 19.

24 Electoral Reform Initiatives in Canadian Provinces, supra, note 5, at 11.
} 


\section{Comparative Experience}

The comparative experience shows that a variety of process options have been used to implement electoral reform. There have only been six major reforms between 1980 and 2010 in established democracies (New Zealand, Japan, France (twice) and Italy (twice)). ${ }^{25}$ In addition, Scotland, Wales and Northern Ireland have adopted new electoral systems for their Parliaments. ${ }^{26}$

In 1993, New Zealand shifted from FPTP to MMP through two referendums. ${ }^{27}$ France changed its electoral system to a proportional system through new legislation in 1985. After a change in government in 1986, the previous voting system was restored through legislative action. ${ }^{28}$ Likewise Japan reformed its electoral system in 1994 through legislative change. ${ }^{29}$ Electoral reform was accomplished in Italy in the 1990s through a referendum, ${ }^{30}$ and in 2005 through the enactment of new legislation. ${ }^{31}$ In Scotland and Wales, the MMP system was brought about through the devolution legislation passed by the U.K. House of Commons. ${ }^{32}$

\section{DEMOCRATIC LEGITIMACY AND ELECTORAL REFORM}

Given the variety of process options that have been used for electoral reform efforts in Canada and globally, this article argues that no single process is mandated for electoral reform. Although some people argue that a referendum is essential for the legitimacy of electoral reform, ${ }^{33}$ the choice of a referendum is not necessarily a neutral one. Based on the

25 Alan Renwick, The Politics of Electoral Reform (Cambridge: Cambridge University Press, 2010), at 5-6, 10. Established democracies are defined as countries that were independent democratic states at the end of the "second wave" of democratization in 1962.

26 Matthew Shugart \& Justin Reeves, "Electoral System Reform in Advanced Democracies" Oxford Bibliographies (May 4, 2015), online: Oxford Bibliographies <http://www.oxfordbibliographies.com>.

27 Renwick, The Politics of Electoral Reform, supra, note 25, at 194.

$28 \quad$ Id., at 103.

$29 \quad$ Id., at 179 .

$30 \quad$ Id., at 176 .

$31 \quad$ Id., at 124

32 R.J. Johnston \& C.J. Pattie, "Campaigning and split-ticket voting in new electoral systems: the first MMP elections in New Zealand, Scotland and Wales” (2002) 21 Electoral Studies 583 , at 584 .

33 For a discussion of whether formal amendments to the Constitution must be subject to a referendum, see Richard Albert, "The Conventions of Constitutional Amendment in Canada" (2016) 53 Osgoode Hall L.J. 399. 
provincial experience with referendums on electoral reform, it is likely that a national referendum on electoral reform would meet a similar fate. ${ }^{34}$

Instead, the key issue is whether the process that ushers in such reform is and appears to be democratically legitimate. To achieve democratic legitimacy, the process should visibly follow three norms: first, political neutrality (or non-partisanship); second, consultation; and third, deliberation. Electoral reform differs from the passage of ordinary legislation because it sets out the very ground rules by which political power is attained. For this reason, the process of electoral reform must be held to a higher standard of democratic legitimacy.

The passage of the Fair Elections Act ${ }^{35}$ under the prior Conservative government provides an instructive example of a process that was illegitimate because it was partisan, hasty, and closed to the views of citizens, experts, Elections Canada, and the opposition parties. ${ }^{36}$ The Liberal government is not exempt from process concerns simply because it secured a mandate for electoral reform by winning the 2015 election. There are many reasons why people voted for the Liberal Party, including the simple objective of removing the Conservative Party from power. It is important not to conflate a Liberal win with support for electoral change. Because electoral reform is inevitably tied to political and partisan calculations, it is essential that the chosen process be and appear to be democratically legitimate by satisfying the norms of political neutrality, consultation, and deliberation.

\section{Political Neutrality and Non-Partisanship}

The norm of non-partisanship ensures that the process is as neutral as possible, which, in turn, helps to prevent the governing party from entrenching itself by selecting rules that favour it at the expense of the other political parties. ${ }^{37}$ This norm is the most difficult to achieve, in large part because the choice of process can have a determinative impact

34 Lawrence LeDuc, "The Failure of Electoral Reform Proposals in Canada" (2009) 61:2 Political Science 21, 36-39.

$35 \quad$ Fair Elections Act, S.C. 2014, c. 12.

36 Remarks of Professor Yasmin Dawood on Bill C-23, An Act to Amend the Canada Elections Act, before the Standing Committee on Procedure and House Affairs, Parliament of Canada (March 31, 2014).

37 For a discussion of partisan self-dealing in the electoral context, see Yasmin Dawood, "Electoral Fairness and the Law of Democracy: A Structural Rights Approach to Judicial Review" (2012) 62 U.T.L.J. 499, at 508-18. 
on the kind of substantive reform that is ultimately adopted. The choice of process can be as partisan as the choice of electoral system.

Any majority government must guard against the perception of selfserving entrenchment by ensuring that the process is as non-partisan as possible. For example, critics denounced the initial Liberal-dominated composition of the proposed all-party committee on the grounds that the government was "stacking the deck" by planning to have the committee recommend preferential balloting - a system which in the past had been endorsed by Prime Minister Trudeau. ${ }^{38}$ A preferential balloting system would have given the Liberals even more seats in the recent election: a gain of 40 seats according to one analysis ${ }^{39}$ and a gain of 20 seats according to another analysis. ${ }^{40}$

One way to achieve the actuality and appearance of political neutrality is to ensure that the other political parties agree with the proposed reform. In the event that a consensus is impossible, it would be important for the proposed reform to secure the support of political parties that collectively achieved at least a majority, and preferably a super-majority, of the popular vote in the 2015 election. The Liberal government decided to adopt the NDP's proposal that the committee's composition follow the proportion of the popular vote rather than the share of seats in the House. Under the new committee structure, there are five Liberals, three Conservatives, two New Democrats, one member of the Bloc Québécois and Green Party leader Elizabeth May, all of whom have voting rights. ${ }^{41}$ The government would need the support of at least either one or two of the opposition parties on the committee in order to propose a change to the electoral system.

The neutrality of the electoral reform process can also be undermined by substantive commitments that skew the process towards any particular outcome. For instance, the government's identification of certain "desired outcomes" could be viewed as skewing the process for or against certain electoral systems. One desired outcome is "[s]table governments that

38 Kady O'Malley, "Can this special committee on electoral reform be saved?" Ottawa Citizen (May 16, 2016) online: Ottawa Citizen <http://ottawacitizen.com/news/politics/kady-canthis-special-committee-on-electoral-reform-be-saved-spoiler-alert-maybe-but-maybe-not>.

39 Eric Grenier, "Change to preferential ballot would benefit Liberals" CBC News (November 26, 2015) online: CBC News <http://www.cbc.ca/>.

$40 \quad$ Paul Fairie, "How the Liberals would have won more seats with ranked ballots" The Globe and Mail (November 18, 2015) online: The Globe and Mail <http://www.theglobeandmail.com>.

${ }_{41}$ Aaron Wherry, "Liberals back down on electoral reform committee, support NDP changes" CBC News (June 2, 2016) online: CBC News <http://www.cbc.ca〉. 
respond to the needs of Canadians". ${ }^{42}$ There is a great deal of debate, however, as to whether PR leads to more or less stability as compared to systems such as FPTP. ${ }^{43}$ The government also announced five guiding principles for electoral reform, and these too could be interpreted to favour some systems over others. For instance, the third principle, "[s]upport accessibility and inclusiveness for all eligible voters, including by avoiding undue complexity in the voting process", 4 disadvantages the MMP system, which has been described by some as being too complex for voters.

\section{Consultation and Deliberation}

The norms of consultation and deliberation ensure that the process has canvassed and considered in detail a wide array of opinions and options. Consultation is connected to the democratic ideal of participation by citizens, ${ }^{45}$ while the norm of deliberation requires that a "collective decision should in some sense be justified by public reasons - that is, reasons that are generally convincing to everyone participating in the process of deliberation." 46 According to the government, the parliamentary committee will engage in "meaningful and extensive consultation with Canadians" and will also seek expert testimony on constitutional and legal issues. ${ }^{47}$

The parliamentary committee must report its findings and recommendations to the House of Commons by December 1, 2016. ${ }^{48}$ However, this self-imposed timeline is unnecessarily hasty, and thereby undermines the norm of deliberation. Given the importance and scale of electoral reform, the deliberative and consultative processes should unfold over a longer time period. Elections Canada also requires time to implement electoral reform, and to have the opportunity to provide commentary on the proposed changes. ${ }^{49}$ More time would also allow the

42 Government of Canada, "Motion to Propose All-Party Parliamentary Committee On Electoral Reform" (May 11, 2016), Government of Canada News, online: Government of Canada News <http://news.gc.ca/web/article-en.do?nid=1063799> [hereinafter "All-Party Committee Motion”].

43 Dennis Pilon, The Politics of Voting: Reforming Canada's Electoral System (Toronto: Emond Montgomery, 2007), at 62-65, 139.

44 All-Party Committee Motion, supra, note 42.

45 Carole Pateman, Participation and Democratic Theory (Cambridge University Press, 1970).

46 James Bohman, Public Deliberation: Pluralism, Complexity, and Democracy (MIT Press, 2000), at 5.

$47 \quad$ All-Party Committee Motion, supra, note 42.

$48 \quad$ Id.

49 Canada, Office of the Chief Electoral Officer, 2016-2017 Report on Plans and Priorities, (2016) at 7, online: Elections Canada <http://www.elections.ca/res/rep/rpp/rpp2016/rpp2016_e.pdf>. 
government to set up an additional process - whether a commission, referendum, or citizens' assembly — that would enhance the actuality and appearance of democratic legitimacy. Legislative committees on electoral reform at the provincial level have often been paired with one or more additional process options, which serve to augment the norms of political neutrality, consultation and deliberation.

\section{IS A CONSTITUTIONAL AMENDMENT REQUIRED?}

Is a constitutional amendment required to bring about electoral reform? Or to be more precise: does Parliament have to follow the general amending formula, which requires approval by at least seven provinces representing 50 per cent of the population, or can Parliament amend the Constitution unilaterally to bring about electoral reform?

Prior to the Supreme Court's decision in the Senate Reference, there was every indication that Parliament had the power to change the electoral model unilaterally under section 44 of the Constitution Act, $1982,{ }^{50}$ subject only to certain constitutional constraints as described in Part III.1 below. Section 44 provides that, "Subject to sections 41 and 42, Parliament may exclusively make laws amending the Constitution of Canada in relation to the executive government of Canada or the Senate and House of Commons." Parliament has unilaterally amended the Constitution with respect to certain electoral matters, such as enlarging the number of seats in the House in the Fair Representation Act. ${ }^{51}$

There is a threshold question of whether electoral reform can be undertaken through Parliament's power in section $91^{52}$ to enact ordinary legislation (like the Canada Elections $A c t^{53}$ ) or whether it amounts to a constitutional amendment that Parliament must undertake through section 44 (like the Fair Representation Act). Although both options involve unilateral action by Parliament, the latter involves a constitutional amendment while the former does not. This article assumes that electoral reform would require a constitutional amendment because most reform proposals would involve a modification of the constitutional text. ${ }^{54}$

\footnotetext{
$50 \quad$ Schedule B to the Canada Act 1982 (U.K.), 1982, c. 11.

$51 \quad$ Fair Representation Act, S.C. 2011, c. 26.

$52 \quad$ See Constitution Act, 1867 (U.K.) 1867, 30 \& 31 Vict., c. 3.

53 S.C. 2000 , c. 9.

54 Certain reforms, such as a change to preferential balloting, could arguably be implemented without touching the constitutional text.
} 
In the wake of the Senate Reference, there is no question that the Court could find that a change in the electoral system requires a constitutional amendment that follows either the general amending formula in section 38 or the unanimous consent formula in section 41. In the Senate Reference, the Court used the idea of an underlying "constitutional architecture" to block reforms that altered the "fundamental nature and role" of the Senate. ${ }^{55}$ As described in more detail in Part III.2 below, the Court held that reforms such as consultative elections would significantly alter the Senate's fundamental nature and role as an independent and complementary legislative body of sober second thought. ${ }^{56}$ The Court could use a similar logic to find that electoral reform amounts to the kind of constitutional amendment that requires substantial provincial consent.

The issue addressed in this article, however, is whether it is possible to interpret the Senate Reference in such a way that the Court can remain consistent with its prior assessment that changes to the electoral system fall within the domain of Parliament. I argue that senate reform and electoral reform are distinguishable, and the Court could therefore find that Parliament can proceed with electoral reform under section 44 . The next section addresses the constitutional constraints imposed by the Court on the electoral process. Parts III. 2 and III.3 describe the Court's decision in the Senate Reference and explore its possible application to electoral reform.

\section{Constitutional Constraints on the Electoral Process Prior to the Senate Reference}

As I have argued elsewhere, the electoral process can be viewed as having a dual constitutional-political nature. ${ }^{57}$ The Court has recognized this duality, finding that the electoral process is political, yet subject to certain constitutional limits. The Court has acknowledged the political dimension of the electoral system, noting that Parliament has the power to choose the design of the electoral system and the details of how the process works. Many aspects of the electoral system are governed by

\footnotetext{
55 This analysis is drawn from Yasmin Dawood, "The Senate Reference: Constitutional Change and Democracy" (2015) 60 McGill L.J. 737 [hereinafter "Dawood"].

56 Senate Reference, supra, note 1, at paras. 57-60.

57 Yasmin Dawood, "Democracy and Dissent: Reconsidering the Judicial Review of the Political Sphere” (2013) 63 S.C.L.R. (2d) 59.
} 
ordinary legislation, such as the Canada Elections Act and the Electoral Boundaries Readjustment Act. ${ }^{58}$

At the same time, there is a constitutional aspect to the electoral process. The first set of constitutional constraints involves the distributional requirements for provincial representation. Sections 51 and 52 of the Constitution Act, 1867, set out the rules for the distribution of representation among the provinces. Section 51A, which is known as the Senate floor rule, provides that no province will have fewer seats in the House of Commons than it has in the Senate. Parliament has changed the distribution of seats, and the size of the House, by passing constitutionalized statutes like the Fair Representation Act. ${ }^{59}$

The second set of constitutional limits involves the right to vote. The right to vote is explicitly protected by section 3 of the Charter, which provides that every citizen has the right to vote for elections for the House of Commons or a provincial legislature and to be qualified for membership in those houses.$^{60}$ In addition, the Court has extended the right to vote beyond the act of filling out a ballot. As I have argued elsewhere, the Court has recognized a "bundle of rights" associated with the section 3 right to vote, ${ }^{61}$ including the right to effective representation ${ }^{62}$ and the right to meaningful participation in a democracy. ${ }^{63}$

The right to effective representation was announced by the Supreme Court in Reference re Provincial Boundaries (Saskatchewan), a case concerning the constitutionality of Saskatchewan's electoral boundaries. ${ }^{64}$ In a five to three decision, McLachlin J. (as she was then) held on behalf of the majority that the electoral boundaries did not infringe the section 3 right to vote. According to the Court, "the purpose of the right to vote enshrined in s. 3 of the Charter is not equality of voting power per se,

\footnotetext{
58 R.S.C. 1985 , c. E-3.

59 S.C. 2011, c. 26.

60 Canadian Charter of Rights and Freedoms, Part I of the Constitution Act, 1982, being Schedule B to the Canada Act 1982 (U.K.), 1982, c. 11, s. 3 [hereinafter "Charter"].

${ }_{61}$ This section is drawn from Yasmin Dawood, "Democracy and the Right to Vote: Rethinking Democratic Rights under the Charter" (2013) 51 Osgoode Hall L.J. 251, at 254-55.

62 Reference re Provincial Electoral Boundaries (Saskatchewan), [1991] S.C.J. No. 46, [1991] 2 S.C.R. 158 (S.C.C.), revg [1991] S.J. No. 111 (Sask. C.A.) [hereinafter "Saskatchewan Reference"].

63 Haig v. Canada (Chief Electoral Officer), [1993] S.C.J. No. 84, [1993] 2 S.C.R. 995 (S.C.C.), affg [1992] F.C.J. No. 921 (F.C.A.) [hereinafter "Haig"]; Figueroa v. Canada (Attorney General), [2003] S.C.J. No. 37, [2003] 1 S.C.R. 912 (S.C.C.), revg [2000] O.J. No. 3007 (Ont. C.A.) [hereinafter "Figueroa"].

64 Saskatchewan Reference, supra, note 62.
} 
but the right to 'effective representation'." ${ }^{95}$ The Court has also recognized the right to "play a meaningful role" in the democratic process. This right was first described in a 1993 decision, Haig v. Canada, ${ }^{66}$ and later elaborated at length in Figueroa $v$. Canada ${ }^{67}$ Writing for the majority in Figueroa, Iacobucci J. stated that section 3 includes not only a right to effective representation, but also "the right of each citizen to play a meaningful role in the electoral process". ${ }^{68}$ The Court has recognized two additional democratic rights in its election law cases - the right to equal participation ${ }^{69}$ and the right to a free and informed vote. ${ }^{70}$ These rights appear to be derived by the Court from an overarching constitutional commitment to the principle of democracy. ${ }^{71}$

The Court has also recognized the political dimension of the electoral system. In Harper v. Canada ${ }^{72}$ and $R$. v. Bryan, ${ }^{73}$ for example, the majority judgments were highly deferential to Parliament because they saw the electoral process as being presumptively "political". In Harper, the majority asserted that the workings of the electoral system are a "political choice" and that the specific details of such political choices should be left for Parliament to determine. ${ }^{74}$ Since Parliament has the right to "choose Canada's electoral model", it is incumbent on the Court to defer to Parliament. ${ }^{75}$ Similarly in Bryan, the majority stated that the Court ought to take a "natural attitude of deference" with respect to election laws. ${ }^{76}$

In Figueroa, LeBel J. posited that the "government has fairly wide latitude in choosing how to design the electoral system and how to

$65 \quad$ Id., at para. 49.

66 Haig, supra, note 63.

$67 \quad$ Figueroa, supra, note 63.

$68 I d$., at para. 25.

69 Libman v. Quebec (Attorney General), [1997] S.C.J. No. 85, [1997] 3 S.C.R. 569 (S.C.C.), revg [1995] J.Q. no 617 (Que. C.A.) [hereinafter "Libman"]; Harper v. Canada (Attorney General), [2004] S.C.J. No. 28, [2004] 1 S.C.R. 827 (S.C.C.), revg [2002] A.J. No. 1542 (Alta. C.A.) [hereinafter "Harper"].

70 Thomson Newspapers Co. v. Canada (Attorney General), [1998] S.C.J. No. 44, [1998] 1 S.C.R. 877 (S.C.C.), revg [1996] O.J. No. 2829 (Ont. C.A.) [hereinafter “Thomson Newspapers"]; Libman, id.; Harper, id.; R. v. Bryan, [2007] S.C.J. No. 12, 2007 SCC 12, [2007] 1 S.C.R. (S.C.C.), affg [2005] B.C.J. No. 1130 (B.C.C.A.) [hereinafter "Bryan"].

71 In the Secession Reference, the Court identified the principle of democracy as one of four principles that "inform and sustain the constitutional text." Reference re Secession of Quebec, [1998] S.C.J. No. 61, [1998] 2 S.C.R. 217, at para. 49 (S.C.C.) [hereinafter "Secession Reference"].

72 Harper, supra, note 69

73 Bryan, supra, note 70.

74 Harper, supra, note 69, at para. 87.

75 Id.

76 Bryan, supra, note 70, at para. 9. 
combine the various competing values at play."77 The choice among various representative options "should be viewed as a matter of political and philosophical preference in which it is not this Court's role to intervene". ${ }^{78}$ In addition, the Constitution "does not require a particular kind of democratic electoral system, whether it is one that emphasizes proportionality and the individual aspects of participation or one that places more emphasis on centrism and aggregation, to be frozen in place". ${ }^{79}$ Justice Iacobucci similarly noted that "The Charter aside, the choice among electoral systems, is as LeBel J. states, a political one and not one in which the Court should involve itself." 80 In addition, he noted that "the Charter is entirely neutral as to the type of electoral system in which the right to vote or to run for office is exercised." 81 The purpose of section 3 is "to protect the right of each citizen to play a meaningful role in the electoral process, whatever that process might be". ${ }^{82}$

The idea that the Constitution does not require a particular electoral system was confirmed in a recent Quebec Court of Appeals decision, which held that the FPTP system is not unconstitutional. ${ }^{83}$ In Gibb $v$. Attorney General of Quebec, the court held that while the electoral system can be challenged in the courts if it violates constitutional rights, the FPTP electoral system does not violate the right to vote, the right to equality, nor the right to effective representation. ${ }^{84}$ Following past Supreme Court precedents, including Figueroa, the court stated that the "Constitution does not require a particular electoral system". ${ }^{85}$

To summarize, a change from one electoral system to another would likely require a constitutional amendment. Given various statements by the Court, however, Parliament could undertake to change the electoral system unilaterally under section 44 , subject to the constitutional limits described above. Most electoral reform options would satisfy these constitutional limits in that they would provide effective representation and meaningful participation, in addition to adhering to the distributional

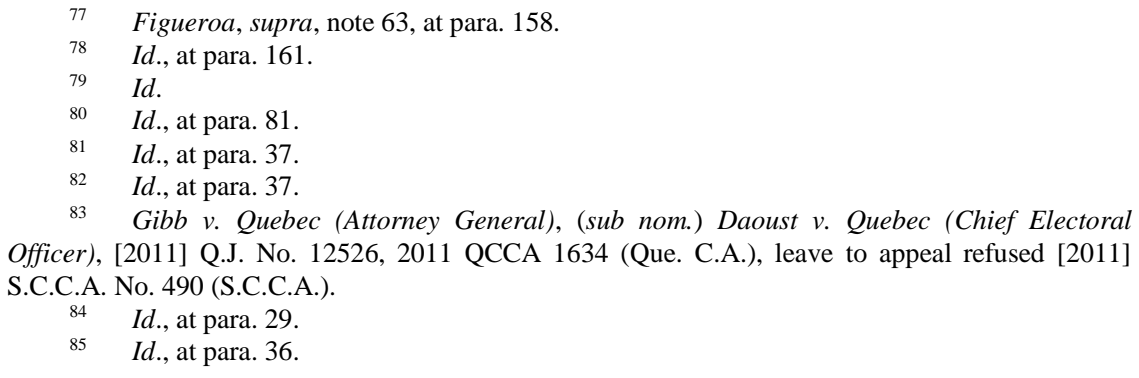


principles for provincial representation. The remaining question is whether the Court's decision in the Senate Reference has changed Parliament's ability to bring about electoral reform under section 44 .

\section{The Senate Reference}

In the Senate Reference, the Supreme Court considered the constitutionality of the government's proposal to unilaterally reform various aspects of the Senate. ${ }^{86}$ The Court rejected the government's position, holding that consultative elections and senatorial term limits could only be implemented by following the " $7 / 50$ rule". The "7/50 rule", which is found in section 38 of the Constitution Act, 1982, requires the consent of the Senate, the House of Commons, and the legislative assemblies of at least seven provinces representing half the population of all the provinces. The abolition of the Senate would require the unanimous consent of Parliament and all the provinces. The wealth and property qualifications of Senators could be repealed in part by Parliament, although a full repeal would require the consent of the Quebec legislature. ${ }^{87}$

Central to the Court's opinion was the idea that the Constitution has an "internal architecture" or "basic constitutional structure". ${ }^{88}$ The Constitution does not simply comprise the constitutional text itself; it must also be understood by reference to previous constitutional cases and the historical context. ${ }^{89}$ The concept of the Constitution's "internal architecture" proved to be of crucial importance since it served as a bar to changes in constitutional practices that do not result from changes to the constitutional text. That is, the Constitution can be amended through changes to its architecture even though the text of the Constitution is left untouched. ${ }^{90}$

\footnotetext{
86 This section is drawn from Dawood, "Senate Reference," supra, note 55. For the argument that the Senate Reference creates ambiguity, see Emmett Macfarlane, "Unsteady Architecture: Ambiguity, the Senate Reference, and the Future of Constitutional Amendment in Canada" (2015) 60 McGill L.J. 883. For additional analyses of the decision, see Adam Dodek, "The Politics of the Senate Reform Reference: Fidelity, Frustration, and Federal Unilateralism" (2015) 60:4 McGill L.J. 623; Kate Glover, "Complexity and the Amending Formula" (2015) 24:2 Const. Forum 9; Peter Hogg, "Senate Reform and the Constitution" (2015) 68 S.C.L.R. (2d) 591.

$87 \quad$ Senate Reference, supra, note 1, at para. 86.

${ }^{88} I d$., at para. 26 (citing Secession Reference, supra, note 71, at para. 50).

$89 \quad I d$. , at para. 25.

$90 \quad I d$
} 
For this reason, the Court concluded that holding consultative elections for Senate seats would amount to a constitutional amendment even though the proposal did not contemplate a change to the formal text of the Constitution. To determine whether or not a particular proposed change amounted to a constitutional amendment, the Court examined whether or not the reform in question would alter the "fundamental nature and role" of the institution..$^{91}$ For the Court, the Senate's fundamental nature and role is that it is a "complementary legislative body of sober second thought". ${ }^{2}$ The Court referred to its decision in the Upper House Reference for the idea that the Senate was intended to be "a thoroughly independent body which could canvass dispassionately the measures of the House of Commons". ${ }^{93}$ The Senate was designed to be independent from the electoral process. ${ }^{94}$ By being appointed, Senators would not have to consider the short-term political objectives that carry weight in an elected arena. ${ }^{95}$ In addition, the Senate was meant to be a "complementary legislative body", rather than a "perennial rival of the House of Commons in the legislative process". ${ }^{96}$ By design, Senators did not have a "popular mandate - they would not have the expectations and legitimacy that stem from popular election." ${ }^{.97}$ Consultative elections would bestow democratic legitimacy on the Senate and would thereby enable it to systematically block the legislation of the House of Commons. ${ }^{98}$ The Senate, however, was not designed to be a systematic obstacle to legislation. ${ }^{99}$ The Court concluded that as a result of consultative elections, the "Senate's fundamental nature and role as a complementary legislative body of sober second thought would be significantly altered" ${ }^{100}$

The Court also determined that the "7/50 rule" (the general amending procedure in section 38) was the default procedure for constitutional amendment. The other procedures for constitutional amendment in Part V were all exceptions to the general procedure. According to the Court, the general amending formula is based on the idea that "substantial provincial

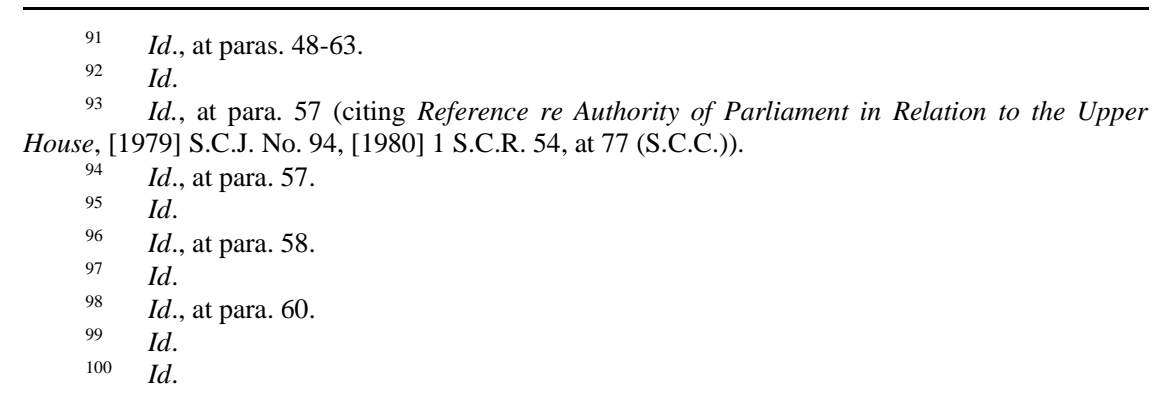


consent must be obtained for constitutional change that engages provincial interests" 101 The purpose of the amending formula is to "constrain unilateral federal powers to effect constitutional change". ${ }^{102}$ As Peter Hogg notes, the Court adopted a similar approach in the Supreme Court Reference, ${ }^{103}$ holding that because the Supreme Court has become constitutionalized over time, Parliament cannot unilaterally make changes to the Court. ${ }^{104}$ While the Court's approach to constitutional amendment is consistent with democratic principles of deliberation and dialogue, it can be faulted for freezing the constitutional order into place particularly since the concept of constitutional architecture can be applied to almost any proposed change to the institutions of government. ${ }^{105}$

Some commentators have concluded that a constitutional amendment involving provincial consent is required for most electoral reform proposals. Michael Pal argues, for instance, that because the Senate Reference limited Parliament's power to unilaterally reform the Senate under section 44, the same constraint would apply to electoral reform. ${ }^{106}$ In his view, changing the electoral system from first-past-the-post would affect provincial interests, and would constitute a fundamental change to the House and the Constitution. ${ }^{107} \mathrm{He}$ argues that less-involved reforms such as moving to a preferential balloting system may be permitted by unilateral Parliamentary action, but that most reforms would require provincial consent. Yaakov Roth and Jonathan Roth argue that the constitutional architecture "plainly presupposes district-based elections", and that the first-past-the-post electoral system has always determined the make-up of the House of Commons. ${ }^{108}$ In addition, wholesale changes to the electoral system engage provincial interests, not least because the

$101 \quad$ Id., at para. 34.

102 Id., at para. 31 (citing P.J. Monahan \& B. Shaw, Constitutional Law, 4th ed. (Toronto: Irwin Law, 2013), at 204).

103 Reference re Supreme Court Act, ss. 5 and 6, [2014] S.C.J. No. 21, 2014 SCC 21, at para. 74 (S.C.C.).

104 Hogg, supra, note 86, at 607, n. 44.

105 Dawood, "Senate Reference", supra, note 55, at 760-61.

106 Michael Pal, "Why Canada's top court must weigh in on electoral reform" The Globe and Mail (January 15, 2016) online: The Globe and Mail <http://www.theglobeandmail.com/opinion/whycanadas-top-court-must-weigh-in-on-electoral-reform/article28198932/>.

107 Id. For further analysis, see Michael Pal, "Constitutional Amendment After the Senate Reference and the Prospects for Electoral Reform” in B. Berger \& S. Lawrence, eds., Constitutional Cases 2015 (2016) 76 S.C.L.R. (2d) 377.

108 Yaakov M. Roth \& Jonathan E. Roth, "Liberals' electoral reform plan is legally futile" The Star (January 18, 2016) online: The Star <https://www.thestar.com/opinion/commentary/2016/01/18/ liberals-electoral-reform-plan-is-legally-futile.html>. 
"strength and composition of provincial delegations in the House of Commons could shift dramatically under a reformed electoral system". ${ }^{109}$

\section{Is Electoral Reform Analogous to Senate Reform?}

Although the Court could undoubtedly find that electoral reform requires provincial consent, it is also possible for the Court to interpret the Senate Reference in such a way that would permit Parliament to engage in unilateral electoral reform. The argument is that because electoral reform can be distinguished from senate reform, it does not require a constitutional amendment involving provincial consent. As such, electoral reform could be treated like Parliament's unilateral decision to expand the size of the House in the Fair Representation Act. This analysis is supported by the Court's pre-Senate Reference cases, which consistently found that the choice of electoral model lay with Parliament, and that the particular model of the electoral system was not itself determined or set by the Constitution.

\section{(a) Constitutional Provisions}

As a start, there are notable differences in the way that the Constitution treats the Senate and the electoral system, respectively. There are a number of provisions in the Constitution Acts, 1867 and 1982, which pertain to the Senate. In the Constitution Act, 1867, the following provisions reference the Senate and/or Senators: sections 17, $18,21,22,23,26,27,28,29,30,31,32,33,34,35,36,39$, and 51A. In the Constitution Act, 1982, the following provisions reference the Senate and/or Senators: sections 38, 41, 42, and 44. By contrast, there is much less reference to the electoral model in the Constitution. The FPTP system is not explicitly mentioned, although there are references to electoral districts. This difference in constitutional treatment reflects the fact that the Senate was indispensable to the creation of the constitutional order in a way that the electoral system was not.

To the extent there is a reference to the electoral system in the Constitution, the provision suggests that Parliament has the power to change it. Section 40 of the Constitution Act, 1867, provides in part that "Until the Parliament of Canada otherwise provides, Ontario, Quebec, Nova Scotia, and New Brunswick shall, for the Purposes of the Election

109 Id. 
of Members to serve in the House of Commons, be divided into electoral districts as follows: ... ." Section 41 also provides that all election laws in the provinces shall apply to the election of members to serve in the House for those same provinces "[u]ntil the Parliament of Canada otherwise provides." Although these sections are spent, they suggest that Parliament has the prerogative to make changes to the electoral system.

Section 40 also provides that each electoral district is "entitled to return One Member" for Ontario, Quebec and New Brunswick. All electoral districts in Nova Scotia are entitled to return one member with the exception of the "County of Halifax [which] shall be entitled to return Two Members". Yaakov Roth and Jonathan Roth suggest that this provision might be interpreted to mean that electoral districts are bound to only have one representative, ${ }^{110}$ in which case the MMP system would not be permitted. However, the provision also begins with the statement "Until the Parliament of Canada otherwise provides", which suggests that the entirety of section 40 , including the requirement that each district return one member, could be changed by Parliament unilaterally.

Another possible argument is that the preamble of the Constitution prohibits electoral reform. Yaakov Roth and Jonathan Roth argue that the "core structure of our electoral system is constitutionally entrenched" because the Founders adopted a "Constitution similar in principle to that of the United Kingdom" as provided in the preamble. ${ }^{111}$ The U.K. House of Commons, they argue, has used first past the post for hundreds of years, and the Canadian House of Commons has done so since the country's inception. In response, Denis Pilon argues that in 1867 the United Kingdom used multi-member ridings, and other kinds of methods including the semi-proportional limited vote. ${ }^{112}$ For this reason, the preamble should not be used to prohibit electoral reform undertaken by Parliament.

The language pertaining to constitutional amendment in the Constitution Act, 1982 also suggests a difference between electoral reform and Senate reform. Section 44 states that "[s]ubject to sections 41 and 42, Parliament may exclusively make laws amending the Constitution of Canada in relation to the executive government of Canada or the Senate or the House." Section 42(1)(b) provides that the general amending formula

110 Roth \& Roth, supra, note 108.

111 Id.

112 Denis Pilon, "You can't hide behind the Constitution to spare us electoral reform" National Post (February 1, 2016) online: National Post <http://news.nationalpost.com/full-comment/dennispilon-you-cant-hide-behind-the-constitution>. 
(the "7/50 rule") must be followed with respect to "the powers of the Senate and the method of selecting Senators". According to the Court in the Senate Reference, section 42(1)(b) covers the implementation of consultative elections. ${ }^{113}$ The phrase "method of selecting Senators" does not apply to only the formal appointment of Senators but also includes the entire selection process, including the compilation of a list of candidates from the election. ${ }^{114}$ For this reason, the implementation of consultative elections is subject to the general amending formula. ${ }^{15}$

By contrast, the amendment provisions do not refer directly to the electoral system. They do, however, place a constraint on electoral reform. Section 42(1)(a) provides that the general amending formula must be followed with respect to any change to the "the principle of proportionate representation of the provinces in the House of Commons prescribed by the Constitution". This provision suggests that as long as any proposed electoral reform does not deviate from these distributional principles, Parliament would not need to follow the general amending formula. No doubt this provision would rule out certain forms of "pure" PR, but it would still allow for other kinds of PR, mixed voting systems, and other models such as preferential ballots to be adopted.

\section{(b) The Fundamental Nature and Role of the Electoral System and the House}

A central feature of the Court's Senate Reference was the idea that the proposed consultative elections would alter the Senate's "fundamental nature and role as a complementary legislative body of sober second thought". ${ }^{116}$ The Court used the "fundamental nature and role" analysis to determine whether consultative elections - a reform that could be implemented without changing the constitutional text - nevertheless amounted to a constitutional amendment.

The "fundamental nature and role" analysis was also used by the Court to determine if the proposed change was the kind of measure that engaged provincial interests. If a particular measure alters the fundamental nature and role of the Senate, it engages provincial interests and thereby triggers the general amending formula. For instance, the

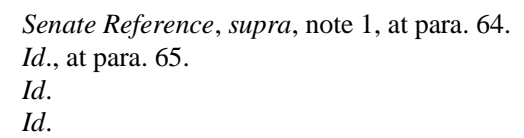


Court asked "whether the imposition of fixed terms for Senators engages the interests of the provinces by changing the fundamental nature or role of the Senate". ${ }^{117}$

If, however, a proposed measure does not change the Senate's fundamental nature and role, it does not engage provincial interests, and it therefore can be implemented unilaterally by Parliament under section 44. For instance, the Court found that the repeal of the net worth requirement for senators did not change the Senate's fundamental nature and role, and therefore did not engage the interests of the provinces. ${ }^{118}$ The Court stated that "[n]either level of government acting alone can alter the fundamental nature and role of the institutions provided for in the Constitution. This said, those institutions can be maintained and even changed to some extent under ss. 44 and 45 , provided that their fundamental nature and role remain intact." 119 According to the Court, section 44 "does not permit amendments that engage the interests of the provinces by modifying the Senate's fundamental nature and role". ${ }^{120}$

The key question, then, is whether electoral reform changes the fundamental nature and role of the electoral system and/or the House of Commons. The fundamental nature and role of any electoral system is to act as a translation device between votes and seats, and thereby enable representation. Although there are differences among the various models, these details do not change the "fundamental" nature and role of the electoral system. In the Senate Reference, the Court stressed that the Senate would, as a result of consultative elections, change from a complementary body of sober second thought to an institutional rival with a popular mandate of its own. A change from one kind of electoral system to another, however, would not amount to a fundamental change of this order. The electoral system would still be translating votes into seats, and its relationship to the other major institutions of government would remain the same.

Alternatively, does a change to the electoral system involve a change to the fundamental role and function of the House? The House would still be a representative body under the mainstream reform options that are usually considered. ${ }^{121}$ The new system would have to ensure that the

\footnotetext{
$117 \quad I d .$, at para. 78.

$118 \quad I d$. , at para. 88.

$119 \quad$ Id., at para. 48.

$120 \quad$ Id., at para. 87.

121 Emmett Macfarlane argues that the interests of the provinces are less important for the House than for the Senate given the distinctive roles that each institution plays in the system of
} 
principle of proportionality among provinces is maintained, so there is some constraint on the options that are permissible. In addition, the proposed reform would have to abide by the Charter requirements in terms of protecting the right to vote, equality rights, and the bundle of derivative rights such as the right to effective representation, the right to meaningful participation, the right to equal participation, and the right to a free and informed vote. Most reform options would abide by these requirements, and the fundamental nature and role of the House as a representative body would not be altered. ${ }^{122}$ Although different systems differ in the details in terms of the kind of representation that is provided, the Court's standard does not inquire at this level of granularity. It is concerned instead with the fundamental nature and role of an institution and under most reform options the House would continue to be a representational body that is designed to reflect the national and collective will.

\section{CONCLUSION}

There are a number of possible options for the process by which electoral reform could take place in Canada, including via a citizens' assembly, a commission, a referendum, and/or a parliamentary committee. This article has argued that although no single option is mandated, the process must visibly follow the norms of political neutrality, consultation and deliberation in order for the proposed reform to be democratically legitimate.

This article also concluded that electoral reform can likely proceed without a constitutional amendment involving provincial consent, provided that the reform is consistent with certain constitutional requirements. The Supreme Court has consistently recognized that the electoral model is political in nature, and that the choice of electoral model falls within the domain of Parliament. Although the electoral system is subject to certain constitutional limits — such as voter rights and the principle of provincial representation - most electoral reform proposals would not violate these limits. While the Senate Reference could be interpreted to require a constitutional amendment

bicameral representation. Emmett Macfarlane, "Constitutional Constraints on Electoral Reform in Canada: Why Parliament is (Mostly) Free to Implement a New Voting System" in B. Berger \& S. Lawrence, eds., Constitutional Cases 2015 (2016) 76 S.C.L.R. (2d) 376, at 408.

122 For an analysis, see Leonid Sirota, "Yes, They Can" Double Aspect Blog (January 19, 2016) online: <https://doubleaspectblog.wordpress.com/2016/01/19/yes-they-can/>. 
with provincial consent for electoral reform, it is also possible for the Court to distinguish electoral reform and find that its earlier precedents on the electoral system remain valid.

In addition, there are significant disadvantages to holding that electoral reform requires a constitutional amendment with provincial consent. Such a course could have a number of unintended consequences, such as requiring provincial consent every time electoral boundaries are redrawn. The 7/50 rule could be imposed every time new seats are added to the House, particularly since such a change affects how many seats are allotted to each province. Many of the electoral rules in the Canada Elections Act arguably affect provincial interests, and these changes could also be subject to the general amending formula. Given how difficult it is to amend the Constitution in Canada, ${ }^{123}$ such a course would only serve to freeze the constitutional order. ${ }^{124}$ In my view, the Court's approach in its law of democracy cases is preferable: the electoral process is generally treated as falling within the domain of Parliament but subject to certain constitutional limits. The Supreme Court not only can, but should, adopt a narrow reading of the Senate Reference that would allow it to distinguish electoral reform from Senate reform.

123 Richard Albert, "The Difficulty of Constitutional Amendment in Canada" (2015) 53:1 Alta. L. Rev. 85.

${ }_{124}$ As Peter Hogg observes, the Court's rejection of Senate reform "condemns the country to the status quo": Hogg, supra, note 86, at 604 . 
